\title{
Analysis of Service Factors that Influence the Bed Occupancy Rate in the Inpatient Room of Royal Prima Medan General Hospital
}

\author{
Wiwin Dwi Handayani ${ }^{1}$, Tan Suyono $^{2 *}$, Sri Lestari Nasution ${ }^{3}$, Ermi Girsang ${ }^{4}$ \\ $1,2,3,4$ Universitas Prima Indonesia \\ *Corresponding Author: \\ Email: tansuyono@unprimdn.ac.id
}

\begin{abstract}
.
The government has a responsibility to ensure that every citizen gets health services. Minimum Service Standards Indicators aim to be a benchmark of achievement in hospital performance. The indicator that is often used is the Bed Occupancy Rate (BOR). The state of the inpatient installation is an internal determinant of increasing satisfaction from consumers (patients). The aim of the research is to help local governments to improve the level of public health. As well as helping Royal Prima General Hospital Medan provide the best health services, and high quality standards. This research is a quantitative analytical-observational study with a cross sectional approach. Performed at the private public hospital Royal Prima Medan. Primary and secondary data collection was carried out in March-May 2021. Data analysis used a quantitative analysis approach; Data editing, data coding, univariate analysis, bivariate analysis. This analysis was carried out by using the Analysis of Variance (ANOVA) test on the program IBM SPSS. The research subjects came from inpatient room respondents from grades 1, 2, and 3. Based on the results of the study, the attitude of medical personnel was significant $(P=0.04)$ towards services. Medical and medical services were not significant $(P=0.13)$ on health services. Public facilities and infrastructure are significant $(P=0.03)$ on health services. Distance and location of settlements are not significant $(P=0.18)$ to health services. In conclusion, the attitude of medical personnel and public facilities affects the patient's interest. Meanwhile, distance, residential location, and medical services did not affect the patient's interest. Suggestions from this research are to improve the performance of medical personnel and hospital workers, by conducting training and training gradual coaching, to support more conducive health services at Royal Prima General Hospital Medan.
\end{abstract}

Keywords : BOR, Health Service, Factors Service, Patient.

\section{INTRODUCTION}

Health is a basic need of every human being. A person cannot fulfill all his life needs if he is in an unhealthy condition. So that health is the capital of every individual to continue his life properly. The government has a responsibility to ensure that every citizen gets quality health services according to their needs. As a basic need, every individual is responsible for meeting the needs of himself and the people he is responsible for, so that basically fulfilling the community's needs for health is the responsibility of every citizen (Kementerian Kesehatan Republik Indonesia, 2019). 
Because the condition of the capacity of Regional Government resources throughout Indonesia is not the same in carrying out the six affairs, the implementation of these affairs is regulated by Minimum Service Standards (SPM) to ensure the availability of these services for all citizens. SPM has at least two functions, namely; Facilitating local governments to provide appropriate public services for the community, and as an instrument for the community in controlling the government's performance in public services in the health sector.

Minimum Service Standards are provisions regarding the type and quality of minimum basic services which are mandatory government affairs that every citizen has the right to obtain. The policy regarding MSS has changed with the enactment of Government Regulation Number 2 of 2018 concerning Minimum Service Standards, as an implementation of the provisions of Article 18 paragraph (3) of Law Number 23 of 2014 concerning Regional Government. With this policy the MSS in the Health Sector underwent a fairly basic change from the previous MSS as stipulated by Permenkes Number 43 of 2016 concerning Standards Minimum Service. Minimum Service Standards Indicators aim to be a benchmark for assessing performance in terms of quantity and quality of hospital performance in health services (Menteri Kesehatan Republik Indonesia, 2019). From the indicators that can be used for hospital performance, the parameter that is often used is the Bed Occupancy Rate (BOR) because it is common and often used in daily activities. This parameter is considered very common and often because it is more specific and faster to evaluate (Menteri Kesehatan Republik Indonesia, 2019). The demand for adequate and equitable health services for the entire community is increasing. With the help of social funds from the government, it is hoped that it can help the community to get decent and satisfying health services.

The government in implementing its policies can evaluate the performance of related hospitals to maintain the quality of service for the community. Hospital performance evaluation can be carried out in the form of BOR monitoring at each hospital that implements the government's social fund system (Menteri Kesehatan Republik Indonesia, 2019).Inpatient installation is a unit of service for hospitalized patients who occupy a nursing bed for the purposes of observation, diagnosis, therapy, medical rehabilitation, and other medical services. The inpatient installation is a core part of the hospital. The role of the inpatient installation as a building facility for a hospital is to support the occurrence of intensive medical action (Suryanti, 2002). In addition to BOR, inpatient installations are another comparison for hospital performance assessment. Coverage of service factors consisting of; inputs, service processes, and outputs, are the units of a hospital institution. In this case, hospitalization relates to medical services performed by medical personnel. Things that affect the state of the inpatient installation are internal determinants of increasing customer satisfaction (patients) (Menteri Kesehatan Republik Indonesia, 2002).The Royal Prima General Hospital 
Medan is a private hospital which is one of the class B private hospitals and will become a referral center in the city of Medan, North Sumatra.

On February 16, 2014, the Royal Prima Hospital Medan was inaugurated by Mr. Ir. H. Tengku Erry Nuradi, M.Sc., as the Deputy Governor of North Sumatra. Granting of Temporary Operational Permit from the North Sumatra Provincial Health Office with No. 440.442/1641/II/2014 on February 14, 2014 signed by Mrs. dr. Siti Hatati Surjantini, M.Kes. as Head of the North Sumatra Provincial Health Office. (Anon., 2021).The percentage of BOR at Royal Prima General Hospital has decreased in 2020. It is known that in the last six months of 2020, the average BOR percentage in each inpatient room was $32 \%$. Meanwhile, in January 2021, the BOR presentation in each inpatient room was 43\%. In April 2021, the percentage of BOR value increased again to $56 \%$. Seeing this event, researchers are interested in observing the causes of the decrease in BOR that occurred at Royal Prima General Hospital Medan .With this research, it is hoped that it can help the local government to improve the level of public health. Researchers also hope that by doing this research, it will indirectly help Royal Prima General Hospital Medan to achieve the hospital's vision, namely; To become a hospital that provides the best health services, high quality standards, and fulfills the needs of patients and their families.

\section{METHODS}

This research is a quantitative analytical-observational study with a cross sectional approach. The data source comes from the results of interviews conducted by researchers to the head of the BPJS Patient Inpatient Room at Royal Prima General Hospital Medan. The data consists of primary data and secondary data. Primary data were obtained from interviews and conclusions from several questionnaires that would be given to authorized officers in the Patient Inpatient Room at Royal Prima General Hospital Medan. Secondary data was obtained from medical record data at Royal Prima General Hospital Medan and related references.

Researchers will conduct a centralized evaluation in the inpatient room where the patient (BPJS and General) will be placed. The input variables that are used for comparison of the BOR are the facilities and infrastructure to support available medical measures. While the medical service process variables include medical personnel and the implementation of medical actions. External variables that can be analyzed in this study are the value of patient satisfaction with the services provided, the distance, and the location of the Royal Prima Hospital. The data search was carried out in the form of a survey of patient satisfaction which was stated in the results of the Questionnaire. All data will be collected, analyzed with IBM SPSS 20 (Statistical Program for Social Science) program for Windows. The results of data analysis will be presented in tabular form with specific explanations and presented at the final stage of the study (Menteri Kesehatan RI, 2005). 


\section{RESULT AND DISCUSSION}

\subsection{Bivariate Analysis}

Table 1. The effect of the attitude of medical personnel in providing services to patients in the Inpatient Room at Royal Prima General Hospital Medan on the BOR value at Royal Prima General Hospital Medan.

\begin{tabular}{|c|c|c|c|}
\hline \multicolumn{3}{|l|}{ BOR $(\%)$} & \multirow[b]{2}{*}{ Total } \\
\hline \multicolumn{2}{|l|}{ Not ideal } & Ideal & \\
\hline tmedical-doctor Disagree Count & 9 & 6 & 15 \\
\hline$\%$ within tmedical-doctor & $60.0 \%$ & $40.0 \%$ & $100.0 \%$ \\
\hline Hesitating Count & 17 & 1 & 18 \\
\hline$\%$ within tmedical-doctor & $94.4 \%$ & $5.6 \%$ & $100.0 \%$ \\
\hline agree Count & 86 & 19 & 105 \\
\hline$\%$ within tmedical-doctor & $81.9 \%$ & $18.1 \%$ & $100.0 \%$ \\
\hline totally agree Count & 54 & 8 & 62 \\
\hline$\%$ within tmedical-doctor & $87.1 \%$ & $12.9 \%$ & $100.0 \%$ \\
\hline
\end{tabular}

\section{Chi-Square Tests}

\begin{tabular}{cc|c|c} 
Value & df & $\begin{array}{c}\text { Asymptotic } \\
\text { Significance (2- } \\
\text { sided) }\end{array}$ \\
\hline Pearson Chi-Square & $8.121^{\mathrm{a}}$ & 3 & .044 \\
\hline Likelihood Ratio & 7,461 & 3 & .059 \\
\hline Linear-by-Linear Association & 2,763 & 1 & .096 \\
\hline N of Valid Cases & 200 & & \\
\hline
\end{tabular}

a. 2 cells $(25.0 \%)$ have expected count less than 5 . The minimum expected count is 2.55 . 
From 15 respondents with the variable of implementing medical or medical services to patients in the Inpatient Room at Royal Prima General Hospital Medan on the BOR value at Royal Prima General Hospital Medan, the majority stated that they did not agree with the BOR Not Ideal as many as 9 people $(60.0 \%)$, while the minority did not agree with the BOR. Ideally as many as 6 people (40.0\%). Statistical test results show that there is an influence of the attitude of medical personnel in providing services to patients in the Inpatient Room of Royal Prima General Hospital Medan on the BOR value at Royal Prima General Hospital Medan, the value of $\mathrm{P}=.044(\mathrm{P}<0.005)$.

Table 2. The effect of the implementation of medical or medical services on patients in the Inpatient Room at Royal Prima General Hospital Medan on the BOR value at Royal Prima General Hospital Medan.

Croostab

\begin{tabular}{|c|c|c|c|c|c|}
\hline \multicolumn{2}{|c|}{ BOR (\%) } & \multirow[b]{2}{*}{ Not ideal } & \multirow[b]{2}{*}{ Ideal } & \multirow{2}{*}{ Total } & \\
\hline & & & & & \\
\hline \multicolumn{2}{|c|}{ Service Disagree Count } & 22 & 9 & & 31 \\
\hline \multirow[t]{8}{*}{ Medical } & & & \multirow[b]{2}{*}{$29.0 \%$} & \multirow{2}{*}{\multicolumn{2}{|c|}{$100.0 \%$}} \\
\hline & $\%$ within Administration & $\begin{array}{l}71.0 \\
0 /\end{array}$ & & & \\
\hline & Hesitating Count & 35 & 4 & \multicolumn{2}{|r|}{39} \\
\hline & $\%$ within Administration & 89.7 & $10.3 \%$ & $100.0 \%$ & \\
\hline & agree Count & 93 & 16 & \multicolumn{2}{|l|}{109} \\
\hline & $\%$ within Administration & $\begin{array}{l}85.3 \\
0 \%\end{array}$ & $14.7 \%$ & $100.0 \%$ & \\
\hline & totally agree Count & 16 & 5 & \multicolumn{2}{|r|}{21} \\
\hline & $\%$ within Administration & $\begin{array}{l}76.2 \\
0< \\
0<\end{array}$ & $23.8 \%$ & $100.0 \%$ & \\
\hline \multicolumn{2}{|c|}{ Total Count } & 16 & 34 & 200 & \\
\hline
\end{tabular}




\section{Chi-Square Tests}

\begin{tabular}{|c|c|c|c|}
\hline & Value & $\mathrm{df}$ & $\begin{array}{l}\text { Asymptotic } \\
\text { Significance } \\
\text { (2-sided) }\end{array}$ \\
\hline Pearson Chi-Square & $5.544^{\mathrm{a}}$ & 3 & .136 \\
\hline Likelihood Ratio & 5.230 & 3 & 156 \\
\hline $\begin{array}{l}\text { Linear-by-Linear } \\
\text { Association }\end{array}$ & .536 & 1 & .464 \\
\hline $\mathrm{N}$ of Valid Cases & 200 & & \\
\hline
\end{tabular}

a. 1 cells (12.5\%) have expected count less than 5 . Theminimum expected count is 3.57

Based on the table above, it shows that of the 31 respondents who disagreed with the majority with the Ideal Hospital BOR as many as 9 people $(29.0 \%)$, while the minority was 22 people (71.0\%). While in the Doubtful category, the majority of BOR Hospital Not Ideal as many as 35 people $(89.7 \%)$ and the minority BOR Ideal as many as 4 people (10.3\%), Agree majority with BOR Not Ideal as many as 93 people $(85.3 \%)$, minority 16 people $(143.7 \%)$, while strongly agree with the majority with not ideal BOR as many as 16 people $(76.2 \%)$, ideal minority as many as 5 people $(23.8 \%)$. The results of statistical tests using the Chi-square test showed that there was no effect of the implementation of medical or medical services on patients in the Inpatient Room at Royal Prima General Hospital Medan on the BOR value at Royal Prima General Hospital Medan with a P value $=0 ., 136(\mathrm{P}>0.05)$. 
Table 3. The influence of public and supporting facilities provided to patients by the hospital in the Inpatient Room of Royal Prima General Hospital Medan for the BOR value at Royal Prima General Hospital Medan

\section{Crosstab}

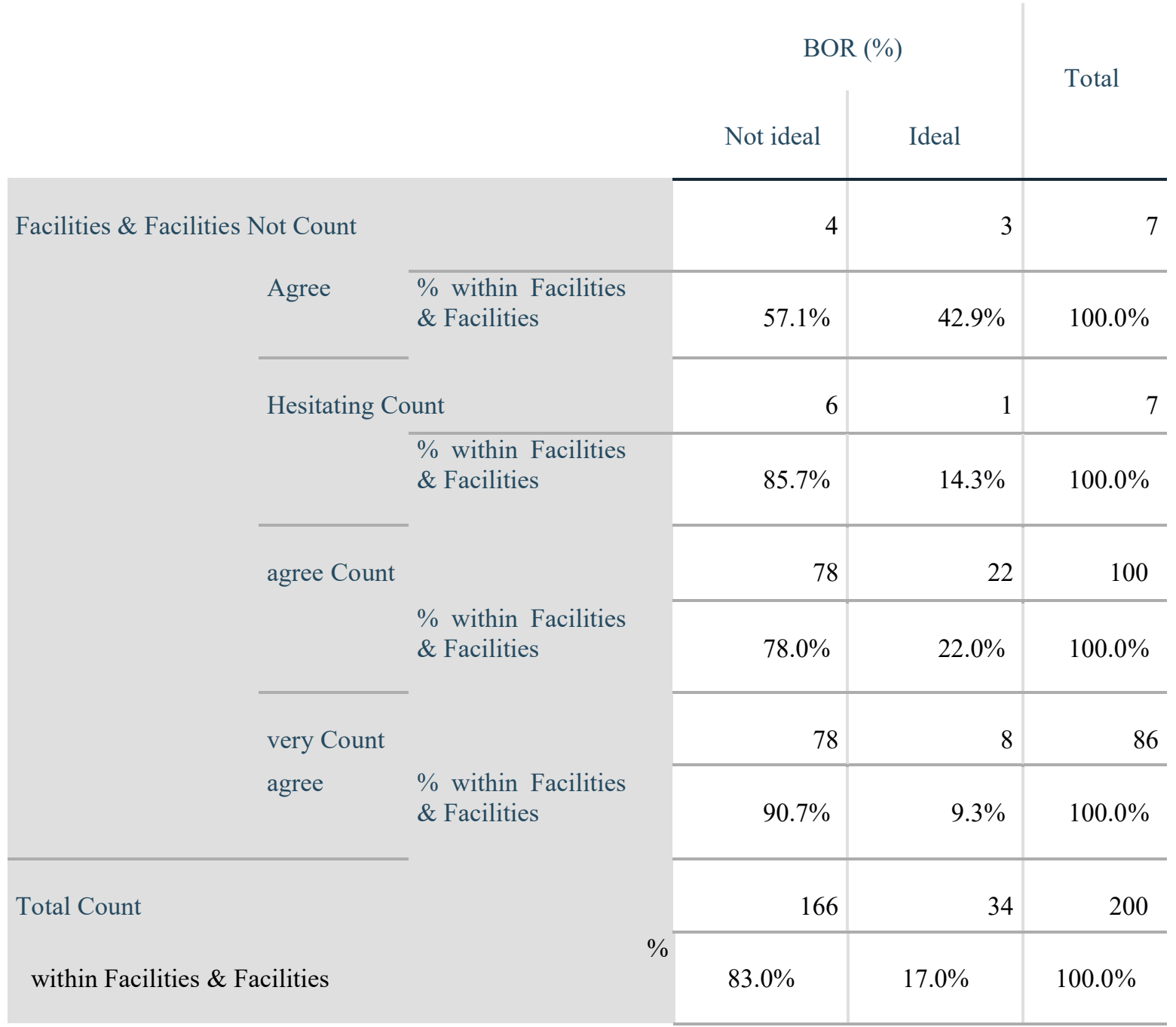




\begin{tabular}{|c|c|c|c|}
\hline \multicolumn{4}{|c|}{ Chi-Square Tests } \\
\hline & Value & $\mathrm{df}$ & $\begin{array}{c}\text { Asymptotic } \\
\text { Significance (2- } \\
\text { sided) }\end{array}$ \\
\hline Pearson Chi-Square & $8,737^{\mathrm{a}}$ & 3 & .033 \\
\hline Likelihood Ratio & 8,440 & 3 & .038 \\
\hline $\begin{array}{l}\text { Linear-by-Linear } \\
\text { Association }\end{array}$ & 7.131 & 1 & .008 \\
\hline $\mathrm{N}$ of Valid Cases & 200 & & \\
\hline
\end{tabular}

a. 2 cells $(25.0 \%)$ have expected count less than 5. The minimum expected count is 1.19 .

Based on the table above, it can be seen that of the 7 respondents with the variables of public and supporting facilities provided to patients by the hospital in the Inpatient Room at Royal Prima General Hospital Medan, the majority of BOR were not ideal as many as 4 people $(57.1 \%)$, while the minority with ideal BOR was as much as 3 people $(42,9 \%)$. Of the 7 respondents who were in doubt, the majority of BOR was not ideal as many as 6 people $(85.7 \%)$ and ideally 1 person $(14.3 \%)$. Of the 100 respondents who agreed the majority with not ideal BOR as many as $78(83.0 \%)$ and the ideal minority as many as 22 people $(17.0 \%)$, while from the variables with strong agreement the majority of BOR was not ideal as many as 78 people $(90.7 \%)$ and a minority of 8 people $9.3 \%$ ). The results of statistical analysis showed that there was an effect of public and supporting facilities provided to patients by the hospital in the Inpatient Room at Royal Prima General Hospital Medan on the BOR value at Royal Prima General Hospital Medan a P value of $0.033(\mathrm{P}<0.05)$ 
Table 4. The effect of patient satisfaction on the services provided by doctors and nurses in the Inpatient Room Patients at Royal Prima General Hospital Medan on BOR at Royal Prima General Hospital Medan

\begin{tabular}{|c|c|c|c|c|}
\hline & & Borl & & \\
\hline & & Not ideal & Ideal & Total \\
\hline Satisfaction Disagree Count & & 7 & 3 & 10 \\
\hline & $\%$ within Satisfaction & $70.0 \%$ & $30.0 \%$ & $100.0 \%$ \\
\hline & $\%$ within BorRS & $4.3 \%$ & $8.8 \%$ & $5.1 \%$ \\
\hline & $\%$ of Total & $3.5 \%$ & $1.5 \%$ & $5.1 \%$ \\
\hline Hesitating Count & & 20 & 4 & 24 \\
\hline & $\%$ within Satisfaction & $83.3 \%$ & $16.7 \%$ & $100.0 \%$ \\
\hline & $\%$ within BorRS & $12.2 \%$ & $11.8 \%$ & $12.1 \%$ \\
\hline & $\%$ of Total & $10.1 \%$ & $2.0 \%$ & $12.1 \%$ \\
\hline agree Count & & 120 & 24 & 144 \\
\hline & $\%$ within Satisfaction & $83.3 \%$ & $16.7 \%$ & $100.0 \%$ \\
\hline & $\%$ within BorRS & $73.2 \%$ & $70.6 \%$ & $72.7 \%$ \\
\hline & $\%$ of Total & $60.6 \%$ & $12.1 \%$ & $72.7 \%$ \\
\hline totally agree Count & & 17 & 3 & 20 \\
\hline & $\%$ within Satisfaction & $85.0 \%$ & $15.0 \%$ & $100.0 \%$ \\
\hline & $\%$ within BorRS & $10.4 \%$ & $8.8 \%$ & $10.1 \%$ \\
\hline
\end{tabular}




\begin{tabular}{|c|c|c|c|c|}
\hline & $\%$ of Total & $8.6 \%$ & $1.5 \%$ & $10.1 \%$ \\
\hline \multirow[t]{4}{*}{ Total Count } & & 164 & 34 & 198 \\
\hline & $\%$ within Satisfaction & $82.8 \%$ & $17.2 \%$ & $100.0 \%$ \\
\hline & $\%$ within BorRS & $100.0 \%$ & $100.0 \%$ & $100.0 \%$ \\
\hline & $\%$ of Total & $82.8 \%$ & $17.2 \%$ & $100.0 \%$ \\
\hline
\end{tabular}

\section{Chi-Square Tests}

Value

\begin{tabular}{|c|c} 
Asymptot \\
ic
\end{tabular}

Significance (2-

\begin{tabular}{lr|r|r}
\hline Pearson Chi-Square & 17.010 & 6 & .009 \\
\hline Likelihood Ratio & 11.28 & 6 & .080 \\
\hline Linear-by-Linear Association & .031 & 1 & .861 \\
\hline N of Valid Cases & 200 & & \\
\hline
\end{tabular}

From the table above shows that of the 10 respondents with satisfaction disagreeing the majority of BOR RS is not ideal as many as 7 people $(70.0 \%)$ while the minority with BOR RS is ideal as many as 3 people (30.0\%). Of the 24 respondents with a level of Satisfaction Doubtful, it can be seen that the majority with BOR RS Not Ideal as many as $20(83.3 \%)$ and the Ideal minority as many as 4 people $(16.7 \%)$, from 144 respondents with a satisfaction level agree that the majority of BOR RS is not ideal as many as 120 people (83.3\%), and a minority of BOR RS is ideal as many as 24 people (16.7\%), from 20 respondents with a level of satisfaction strongly agree the majority of BOR RS is not ideal as much as $85.0 \%$ and the minority of ideal hospital BOR 3 people $15.0 \%$. The results of statistical analysis showed that there was an effect of patient satisfaction by the hospital in the Inpatient Room at Royal Prima General 
Hospital Medan on the BOR value at Royal Prima General Hospital Medan with a P value of $0.009(\mathrm{P}<0.05)$

Table 5. The effect of distance and location of Royal Prima Hospital on BOR value at Royal Prima General Hospital Medan

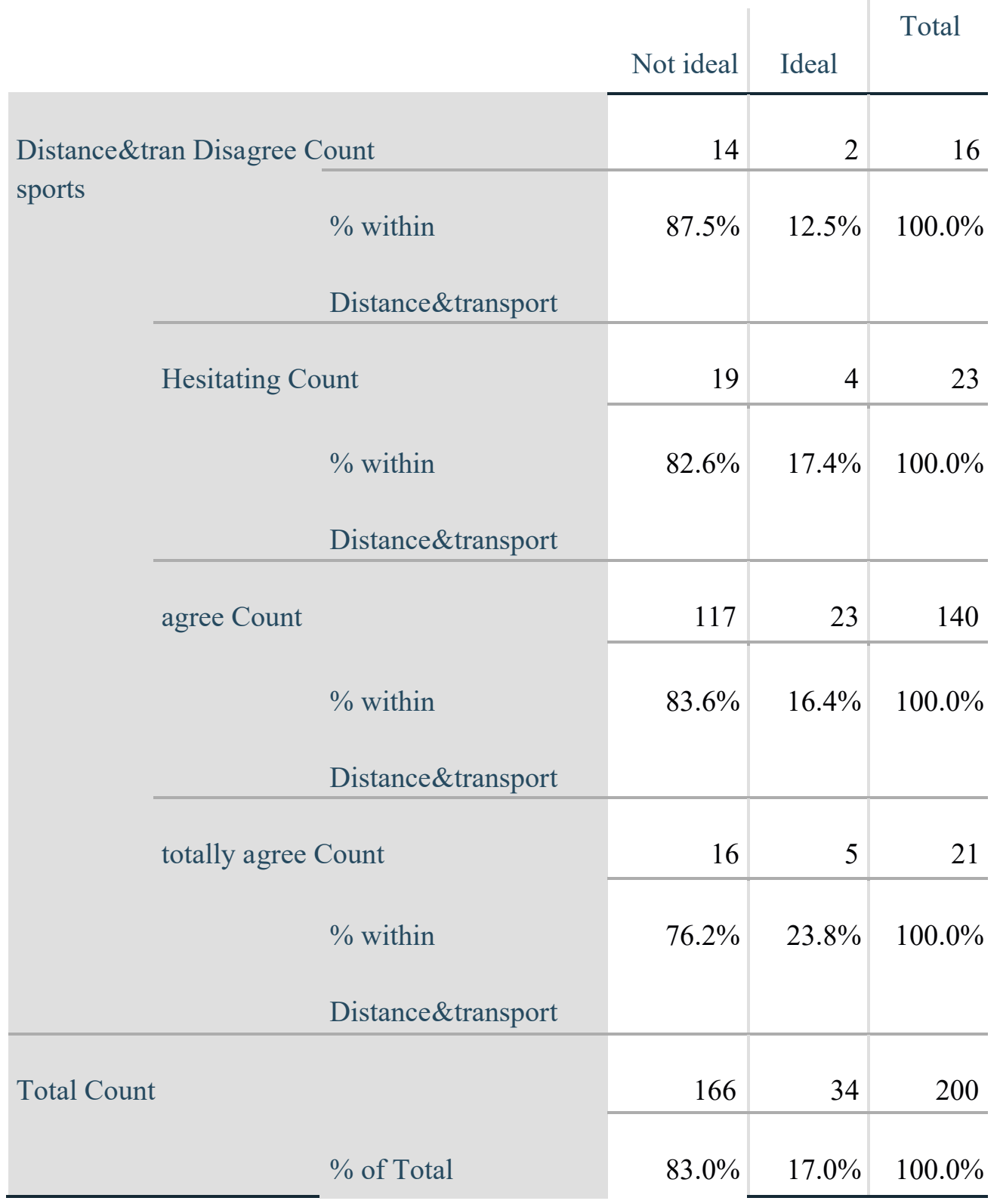




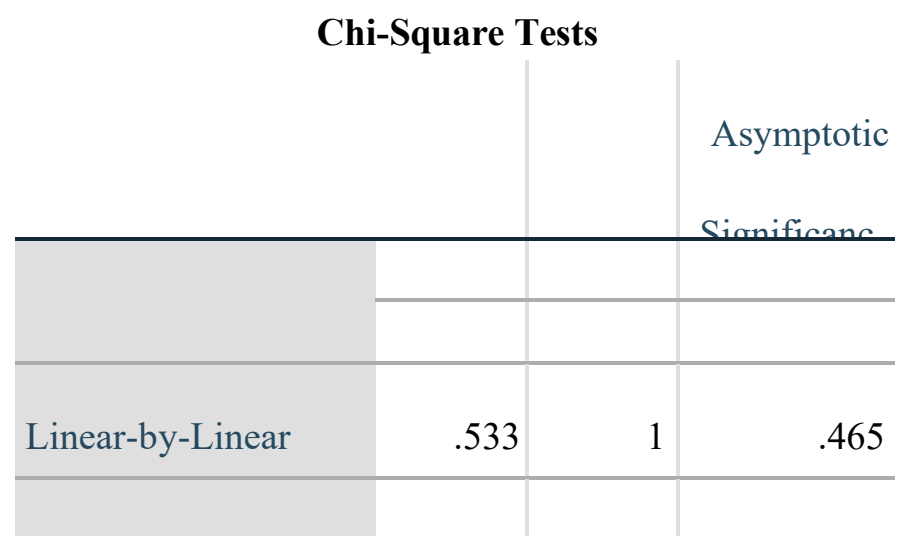

a. 3 cells $(37.5 \%)$ have expected count less than 5 . The minimum expected count is 2.72 .

From 16 respondents in the category of distance and transportation, the majority with BOR are not ideal as many as 14 people (87.5\%), and the minority BOR

\section{CONCLUSIONS AND RECOMMENDATION \\ 1.1 Conclusion}

Based on the results of the analysis conducted from the results of a survey of patients in the inpatient room at Royal Prima General Hospital Medan, it can be concluded that;

1. The attitude of medical personnel in providing services affects the patient's interest in receiving health services at Royal Prima General Hospital Medan

2. Appropriate medical action does not affect the patient's interest in receiving health services at Royal Prima General Hospital Medan.

3. Public facilities and infrastructure affect patient interest in receiving health services at Royal Prima General Hospital Medan.

4. The services provided by doctors and nurses affect patient satisfaction and interest in receiving health services at Royal Prima General Hospital Medan.

5. The distance and location of the patient to the location of the Royal Prima General Hospital Medan does not affect the patient's interest in receiving services at the Royal Prima General Hospital Medan.

6. Private transportation facilities as well as those provided by Royal Prima General Hospital Medan, affect patient interest in receiving health services at Royal Prima General Hospital Medan.

\subsection{Suggestions}

Based on the results of the analysis of surveys and in-depth interviews that have been carried out, suggestions that can be submitted from researchers are;

1. Improve the performance of medical personnel and hospital workers, by conducting training and coaching gradually. This is to create synchronization between 
workers and medical personnel so that communication problems with consumers (patients) can be avoided.

2. Improve the facilities and infrastructure provided by the hospital. This includes the number of proper beds, the number of rooms, equipment in the isolation room, and the number of other facilities to support more conducive health services at Royal Prima General Hospital Medan.

\section{REFERENCES}

[1] Anon., 2021. RSU Royal Prima. [Online] dapat di akses di: http://www.royal prima.com. Diakses 1922021.

[2] Azharatul Jannah. 2016. Analisis Penilaian Efisiensi Penggunaan Tempat Tidur Ruang

[3] Rawat Inap RSUD Tipe B di Kota Makassar Tahun 2016. Makassar. Hendricks, 2021. Occupancy Rate: Definition \& Formula. [Online] dapat di akses di:

[4] https://study.com/academy/lesson/occupancy-rate-definition formula.html. Diakses 242021.

[5] Depkes,RI, 2005. Petunjuk Pengisian, Pengolahan, dan Penyajian Data Rumah Sakit. Jakarta.

[6] Hussein, U., 2003. Metode Riset Bisnis. Jakarta: PT. Gramedia Pustak Utama. Kotler, Philip dan Keller. 2007. Manajemen Pemasaran. Jakarta: PT. Indeks

[7] Menteri Kesehatan Republik Indonesia , 2005. Peraturan Menteri Kesehatan Republik Indonesia tentang Indikator Kinerja Rumah Sakit. Jakarta: Departemen Kesehatan Republik Indonesia.

[8] Menteri Kesehatan Republik Indonesia, 1994. Buku Pedoman Upaya Peningkatan Mutu Pelayanan Rumah Sakit (Konsep Dasar dan Prinsip). Jakarta: Direktorat Jenderal Pelayanan Medik.

[9] Menteri Kesehatan Republik Indonesia, 2002. Keputusan Menteri Kesehatan Republik Indonesia tentang Pedoman Penyusunan Standar Pelayanan Minimal Rumah Sakit. Jakarta: Direktorat Jenderal Pelayanan Medik Departemen Kesehatan RI.

[10] Menteri Kesehatan Republik Indonesia. 2008. Peraturan Menteri Kesehatan Republik Indonesia Nomor 290 Tahun 2019 tentang Persetujuan Tindakan Kedokteran. Jakarta.

[11] Menteri Kesehatan Republik Indonesia, 2019. Peraturan Menteri Kesehatan RI Nomor 4 tentang Standar Teknis Pemenuhan Mutu Pelayanan Dasar pada Standar Pelayanan Minimal Bidang Kesehatan. Jakarta, Direktorat Jendral Kementrian kesehatan Republik Indonesia.

[12] Notoatmodjo, S., 2010. Metodologi Penelitian Kesehatan. Jakarta: Rineka Cipta. Pasaribu, P., 2003. Determinan Faktor Yang Mempengaruhi Rendahnya Pemanfaatan

[13] Tempat Tidur (Bed Occupancy Rate / BOR) Di RSU Sipirok Kabupaten Tapanuli Selatan. Medan, Universitas Sumatera Utara.

[14] Pemerintah Republik Indonesia.Undang Undang Republik Indonesia no. 09 Tahun 2004 tentang Praktik Kedokteran. Jakarta.

[15] Pemerintah Republik Indonesia, 2009. Undang-Undang Republik Indonesia Nomor 44 tentang Rumah Sakit. Jakarta, Dewan Perwakilan Republik Indonesia.

[16] Permerintah Republik Indonesia, 2011. Undang-Undang Nomor 24 tentang Badan Penyelenggara Jaminan Sosial. Jakarta: Dewan Perwakilan Republik Indonesia. 
[17] Simbolon, M. M. 2003. Ekonomi Transportasi. Ghalia Indonesia. Jakarta

[18] Sugiyono, 2015. Metode Penelitian Kuantitatif, Kualitatif dan $R \& D$. Bandung: PT. Alfabeta.

[19] Suryanti, N., 2002. Faktor-faktor yang Berhubungan dengan Lamanya Waktu Proses Pendaftaran Pasien Rawat Inap di Rumah Sakit Pondok Indah. Jakarta: Universitas Indonesia.

[20] Susanto, 1999. Analisis Faktor-Faktor yang Mempengaruhi BOR (Bed Occupancy Rate) Rumah Sakit Roemani Semarang. Semarang: Universitas Dipenegoro.

[21] Suwarman, Ujang. 2004. Perilaku Konsumen Teori dan Penerapannya dalam Pemasaran. PT Ghalia Indonesia. Bogor 